HELMINTHOLOGIA, 57, 4: 361 - 375, 2020

\title{
Vertical distribution of soil free-living nematode in a playa habitat in the North-Western Negev desert, Israel
}

\author{
C. HU ${ }^{1,2}$, S. PEN-MOURATOV ${ }^{1}$, Y. STEINBERGER ${ }^{1, *}$
}

${ }^{1}$ The Mina and Everard Goodman Faculty of Life Sciences, Bar-llan University, Ramat-Gan 52900, Israel,

*E-mail: steinby@mail.biu.ac.il; ${ }^{2}$ Institute of Plant Protection and Soil Fertilizer, Hubei Academy of Agricultural Sciences, Key Laboratory of Fertilization from Agricultural Wastes, Ministry of Agriculture and Rural Affairs, Wuhan, 430064, P. R. China

Article info

Received December 13, 2019

Accepted May 4, 2020

\section{Summary}

In order to investigate the vertical distribution of soil nematode community under a playa area in the Nizzana inter-sand dune area in the north-western Negev Desert of Israel, soil samples were collected from 0 - 10, $10-20,20-30,30-40$, and 40 - $50 \mathrm{~cm}$ depths in the playa and loessial plain area (as control) during the dry and wet seasons. Each of soil samples was determined for soil moisture, organic matter concentration, electrical conductivity, and nematode community structure and biodiversity. The results revealed that soil moisture, organic matter, electrical conductivity, total nematode abundance and trophic groups were significantly influenced by sampling positions $(P<$ $0.0001)$ and depths $(P<0.05)$ and significant interaction effect of position and depth $(P<0.05)$ was also found. Total number of nematodes in the playa area ranged from 1 to 15 individuals per $100 \mathrm{~g}$ dry soil, whereas they ranged from 60 to 631 individuals per $100 \mathrm{~g}$ dry soil in the loessial plain area. The greatest nematode number was found in $0-10 \mathrm{~cm}$ soil depth and the lowest nematode number was found in $40-50 \mathrm{~cm}$ soil depth. Total number of nematodes, bacterivores, fungivores, plant parasites and omnivores-predators were significantly $(P<0.05)$ greater in the loessial plain area than that in the playa area in all sampling depths under the dry and wet seasons. Total thirteen genera were found in the playa area, with Acrobeloides as the dominant genus, whereas there were fifty-five genera, with Acrobeles as the dominant genus in the loessial plain area. Nematode ecological indices, such as fungivores/bacterivores ratio $(\mathrm{F} / \mathrm{B})$, nematode channel ratio (NCR), trophic diversity $(T)$, Shannon Index $\left(H^{\prime}\right)$, genus dominance $(\lambda)$, species richness $(S R)$, maturity index (MI), modified maturity index (MMI), Enrichment Index (EI) and Structure Index (SI) were significantly $(P<0.01)$ differentiated between sampling locations. As conclusion, soil free-living nematode inhabited mostly the upper soil layers $(0-20 \mathrm{~cm})$ and the number of nematode had gradually decreasing trend with soil depths increasing in the playa area. Moreover, each soil layer had a little nematode abundance and community diversity in the playa area in contrast to loessial plain area during the dry and wet seasons. Sampling sites and depths significantly effected on soil properties, nematode abundance and trophic groups, but nematode ecological indices were affected only by sampling sites.

Keywords: vertical distribution; soil nematode community; biodiversity; playa area; loessial plain area

\footnotetext{
* - corresponding author
} 


\section{Introduction}

Inter-sand dune desert sites are known to be among the most prominent locations for generating playa surfaces characterized by compact floors, salt pavements, carbonate surfaces, and a high percentage (50\% or more) of clay lacking microbiotic crusts (Breckle et al., 2008; Yu et al., 2012). Most of the playa area lack vegetation cover and are classified as a Solonchaks soil type which is known as a typical soil profile with a takyric surface (Pen-Mouratov et al., 2011). Such physical and chemical soil properties have a strong influence on the vertical flow of water by playing a crucial function in soil biotic community composition, density, and diversity (Kidron \& Yair, 2001; Guan et al., 2015; Siebert et al., 2019).

Soil nematode community is known to be among the important components of soil fauna, by being of great abundance ( $>3$ million $\mathrm{m}^{-2}$ at some sites) (Yeates, 2003; Liu et al., 2019). Moreover, due to their feeding behavior they can be divided into at least five trophic groups or functional guilds (Yeates et al., 1993; Hu et al., 2018). Therefore, they are regarded as fulfilling a central position in the soil detritus food web (Neher, 2001). Due to their various trophic property, soil free living nematodes are a great bioindicator in the soil and can respond to sand soil environmental changes (Wall et al, 2002; Jiang et al., 2007; Zhang et al., 2009).

Most of the studies on sand dune ecosystems have been oriented toward costal sand dunes. For example, Goralczyk (1998) studied the nematode population as bioindicators in a coastal sand dune elucidating their importance as good indicators in the plant succession process in bare dunes. Wall et al. (2002) observed that soil nematode abundance, diversity, trophic structure and composition were related to soil factors along a coastal sand dune succession. Liang et al. (2005) studied the vertical distribution of bacterivorous nematodes under different land uses. Ou et al. (2005) investigated the vertical distribution of soil nematodes in an aquic brown soil of China. Jiang et al. (2007) studied the vertical distribution of soil nematodes in the Horqin Sandy Land, Northeast China. Pen-Mouratov et al. (2008b) observed the vertical distribution of soil free-living nematode communities in the Tehuacán Desert, Mexico. Zhang et al. (2010) reported the spatial distribution of soil nematode communities in stable and active sand dunes of Horqin Sandy Land. Yang et al. (2018) studied the impact of human trampling on nematode community in a desert ecosystem.

An important gap in the knowledge on the soil free living nematode community structure in desert inter-sand dune ecosystem raised our interest, due to a unique combination between a xeric environment and sandy soil physical characteristics. Furthermore, two main biotopes can be found in this unique inter-dune area: the playa system is characterized by a thick crust with low water infiltration and the sandy system with high water infiltration rates. Moreover, due to the lack of moisture, unpredictability followed by different rates of water infiltration between the two systems, the food randomness availability for the nematode community becomes even more critical. Therefore, the vertical distribution of the nematode community and its trophic composition aspect were found to be even more inspiring.

The aim of this study was to determine the vertical distribution of soil free living nematode community representing a playa and a loessial plain area in a desert inter-sand dune ecosystem under two - wet and dry - extreme environmental conditions in the North-Western Negev Desert, Israel.

\section{Materials and Methods}

\section{Study site}

Study site (30 $\left.53^{\prime} 14^{\prime \prime} \mathrm{N}, 34^{\circ} 25^{\prime} 15^{\prime \prime} \mathrm{E}\right)$ is located at the Nizzana sand dune site within the Hallamish dune field eastern extension of the northern Sinai dune field - western Negev Desert, Israel (Yair, 1990). The dune field comprises longitudinal dunes aligned west-east, are 15 to $20 \mathrm{~m}$ high and are separated by a $50 \mathrm{~m}$ to 200 $\mathrm{m}$ wide interdune. The Nizzana experimental site is located about $45 \mathrm{~km}$ inland from the Mediterranean Sea. Mean annual precipitation is $95 \mathrm{~mm}$ and occurs during the winter months (November - April) and the average monthly temperatures are $9^{\circ} \mathrm{C}$ in January and $25^{\circ} \mathrm{C}$ in August. Potential annual evaporation is in the order of 2200 mm (Kidron, 2001; Kidron \& Yair, 2001; Keck et al., 2016).

The playa area is a geomorphological inter-sand dune desert site unit comprised of thin, dense layers (1 - $2 \mathrm{~mm}$ thick) covered with dark brown clay skins, followed by $3 \mathrm{~cm}$ of angular blocky, deeper down, single grained sandy layers, with very few tubules and holes, alternating with loamy units, having a massive blocky structure (Kidron et al., 2009). All layers are nearly horizontal with textural boundaries, indicating a sedimentary origin and playa area soil riches in clay and silt and have low or no vegetation cover (Yair, 1990). The rusty mottles show that anaerobic conditions with stagnant water occur from time to time (Pen-Mouratov et al., 2011). The clayey layers are dense with pore sizes mainly in the range of $10-50 \mu \mathrm{m}$, thus retarding water infiltration and movement. Carbonate content at such places may exceed $30 \%$, with an alkaline $\mathrm{pH}$. These geomorphological formations are surrounded by a sandy loessial plain area. This plain area soils have a surface crust, which is classified as a platy surface structure, with shallow cracks $1-2 \mathrm{~mm}$ deep filled with windblown sand. The lower part of the crust has a vesicular structure. The distribution of vegetation is mainly the perennial Chenopodiaceous species, Anabasis articulate in the inter-sand dune valley (Breckle et al., 2008).

\section{Sampling \\ Soil samples were collected at the study site at the end of the summer season, representing the driest period and in the middle of the winter season, representing the wet season, using a $7-\mathrm{cm}$ diameter soil auger. Soil samples from the 0 to $50 \mathrm{~cm}$ at $10 \mathrm{~cm}$ intervals (corresponding to $0-10,10-20,20-30,30-40$, and $40-50 \mathrm{~cm}$ depths, four replicates) were randomly collected from both playa and loessial plain areas (as control). Each of the soil samples was deposited in an individual plastic bag which was}


Table 1. Soil physico-chemical propertites in the playa and loessial plain areas (as control) under the dry and wet seasons.

\begin{tabular}{|c|c|c|c|c|c|c|}
\hline \multirow{2}{*}{ Treatment } & \multicolumn{3}{|c|}{ Dry season } & \multicolumn{3}{|c|}{ Wet season } \\
\hline & $\mathrm{SM}^{*}(\%)$ & OM (\%) & $\mathrm{EC}\left(\mathrm{ms} \mathrm{cm}^{-1}\right)$ & SM (\%) & OM (\%) & $\mathrm{EC}\left(\mathrm{ms} \mathrm{cm}^{-1}\right)$ \\
\hline \multicolumn{7}{|l|}{$0-10 \mathrm{~cm}$} \\
\hline playa & $1.28 \pm 0.73 a^{* *}$ & $0.25 \pm 0.05 a$ & $2.20 \pm 1.15 a$ & $7.16 \pm 1.70 \mathrm{a}$ & $0.14 \pm 0.07 a$ & $1.97 \pm 0.63 a$ \\
\hline loessial plain & $0.11 \pm 0.05 b$ & $0.07 \pm 0.04 b$ & $0.05 \pm 0.00 \mathrm{~b}$ & $1.93 \pm 0.54 b$ & $0.05 \pm 0.04 b$ & $0.08 \pm 0.01 b$ \\
\hline \multicolumn{7}{|l|}{$10-20 \mathrm{~cm}$} \\
\hline playa & $2.42 \pm 0.68 \mathrm{a}$ & $0.18 \pm 0.03 a$ & $3.35 \pm 0.59 a$ & $5.44 \pm 0.53 a$ & $0.16 \pm 0.13 a$ & $1.77 \pm 0.32 \mathrm{a}$ \\
\hline loessial plain & $0.09 \pm 0.03 b$ & $0.07 \pm 0.04 b$ & $0.05 \pm 0.00 \mathrm{~b}$ & $1.14 \pm 0.15 b$ & $0.04 \pm 0.03 a$ & $0.07 \pm 0.01 b$ \\
\hline \multicolumn{7}{|l|}{$20-30 \mathrm{~cm}$} \\
\hline playa & $3.08 \pm 0.95 a$ & $0.13 \pm 0.03 a$ & $3.03 \pm 0.75 a$ & $6.75 \pm 0.89 a$ & $0.14 \pm 0.07 a$ & $2.85 \pm 0.97 a$ \\
\hline loessial plain & $0.13 \pm 0.03 b$ & $0.06 \pm 0.06 b$ & $0.05 \pm 0.00 \mathrm{~b}$ & $0.84 \pm 0.17 \mathrm{~b}$ & $0.02 \pm 0.00 \mathrm{~b}$ & $0.07 \pm 0.01 b$ \\
\hline \multicolumn{7}{|l|}{$30-40 \mathrm{~cm}$} \\
\hline playa & $3.81 \pm 1.05 a$ & $0.10 \pm 0.02 a$ & $2.99 \pm 0.68 a$ & $5.69 \pm 0.90 a$ & $0.15 \pm 0.08 a$ & $2.63 \pm 0.39 a$ \\
\hline loessial plain & $0.16 \pm 0.06 b$ & $0.03 \pm 0.02 b$ & $0.06 \pm 0.01 b$ & $0.80 \pm 0.17 \mathrm{~b}$ & $0.02 \pm 0.00 \mathrm{~b}$ & $0.06 \pm 0.00 \mathrm{~b}$ \\
\hline \multicolumn{7}{|l|}{$40-50 \mathrm{~cm}$} \\
\hline playa & $1.23 \pm 1.35 a$ & $0.04 \pm 0.04 a$ & $1.09 \pm 0.75 a$ & $3.47 \pm 1.65 a$ & $0.10 \pm 0.05 a$ & $1.83 \pm 0.80 \mathrm{a}$ \\
\hline loessial plain & $0.42 \pm 0.40 \mathrm{a}$ & $0.05 \pm 0.05 a$ & $0.06 \pm 0.03 b$ & $0.80 \pm 0.12 b$ & $0.04 \pm 0.01 b$ & $0.07 \pm 0.01 b$ \\
\hline
\end{tabular}

*SM: soil moisture; OM: soil organic matter content; EC: electrical conductivity.

${ }^{* *}$ Means and standard deviation from four replicates, different letters at each soil layer in a column denote significant differences as assessed by $t$-test $(P<0.05)$.

placed in an insulated container and transported to the laboratory. These soil samples were kept in cold storage at $4^{\circ} \mathrm{C}$ until processing. All soil samples were sieved (2 mm mesh size) before biological and chemical analysis in order to remove root particles and other organic debris.

\section{Laboratory analysis}

Soil moisture - was determined gravimetrically by drying the samples at $105^{\circ} \mathrm{C}$ for $48 \mathrm{~h}$. The values were expressed as percentage of dry weight.

Organic matter concentration - was determined by oxidization dry soil sample with dichromate in the presence of $\mathrm{H}_{2} \mathrm{SO}_{4}$, without application of external heat (Rowell, 1994).

Electrical conductivity - was determined on a $5 \mathrm{~g}$ subsample that was agitated (half-hour at room temperature) with $50 \mathrm{ml}$ distilled water. The filtrated solution was analyzed using a TH-2400 conductivity meter $\left(\mathrm{ms} \mathrm{cm}^{-1}\right)$.

Soil free-living nematodes - were extracted from $100 \mathrm{~g}$ fresh soil samples using the Baermann funnel procedure (Cairns, 1960) and nematode populations were expressed per $100 \mathrm{~g}$ dry mass soil. The recovered organisms were counted and preserved in formalin (Steinberger \& Sarig, 1993). Total one hundred individuals from each samples were randomly picked and used for identification to genus level, according to esophageal and morphology character- istics using an inverted compound microscope (Mal \& Lyon, 1975; Ying, 1998).

Nematode ecological indices calculation and data statistical analysis

The data were analyzed using the following approaches: (1) total nematode number in $100 \mathrm{~g}^{-1}$ dry soil (TN); (2) trophic groups, including bacterivores $(\mathrm{BF})$, fungivores (FF), plant parasites (PP), omnivores-predators (OP) (Yeates, et al., 1993; Liang et al., 1999; Pen-Mouratov et al., 2004); (3) F/B, fungivores/bacterivores ratio (Twinn, 1974); (4) NCR, nematode channel ratio, where NCR=BF/ (BF+FF) (Yeates, 2003); (5) T, trophic diversity, $T=1 / \sum p i^{2}$, in which pi is the proportion of the $i$-th trophic group in the nematode community (Heip et al., 1988); (6) H', Shannon Index, H' = - $\sum$ pi(Inpi), where $p i$ is the proportion of individuals in the $i$-th taxon (Shannon \& Weaver, 1949); (7) Simpson index for dominance $(\lambda)$, where $\lambda=p i^{2}$ (Simpson, 1949); (8) SR, species richness, SR = (S$1) / \ln (N)$, where $S$ is the number of taxa and $N$ is the number of individuals identified (Yeates \& King, 1997); (9) MI, maturity index, $\mathrm{MI}=\sum$ vipi, where $v i$, is the $c-p$ value for free-living nematodes assigned by Bongers (1990) to the $i$-th nematode genus and $p i$ is the proportion of the genus in the nematode community; (10) MMI, modified maturity index, including plant-feeding nematodes, MMI $=\sum$ vipi, where vi is the $c-p$ value for free-living and plant parasitic 
Table 2. Univariate analysis of variance of the soil properties, nematode population and ecological indices.

\begin{tabular}{|c|c|c|c|c|c|c|c|c|c|c|c|c|}
\hline \multirow{2}{*}{ Index } & \multicolumn{2}{|c|}{ Location (L) } & \multicolumn{2}{|c|}{ Depth (D) } & \multicolumn{2}{|c|}{ Season (S) } & \multicolumn{2}{|c|}{$L \times D$} & \multicolumn{2}{|c|}{$L \times S$} & \multicolumn{2}{|c|}{$D \times S$} \\
\hline & $F$-value & $P$-value & $F$-value & $P$-value & $F$-value & $P$-value & $F$-value & $P$-value & $F$-value & $P$-value & $F$-value & $P$-value \\
\hline \multicolumn{13}{|c|}{ Soil properties } \\
\hline SM' & 139.81 & $<0.0001$ & 6.36 & 0.0002 & 139.81 & $<0.0001$ & 7.12 & $<0.0001$ & 45.04 & $<0.0001$ & 6.80 & 0.0001 \\
\hline OM & 1.16 & $<0.0001$ & 4.95 & 0.0016 & 1.16 & NS & 2.72 & 0.0376 & 0.54 & NS & 1.64 & NS \\
\hline EC & 1.73 & $<0.0001$ & 5.25 & 0.0011 & 1.73 & NS & 5.35 & 0.0009 & 2.02 & NS & 2.45 & NS \\
\hline \multicolumn{13}{|c|}{ Trophic group } \\
\hline TN & 69.36 & $<0.0001$ & 6.42 & 0.0002 & 8.88 & 0.0042 & 6.21 & 0.0003 & 7.63 & 0.0076 & 1.08 & NS \\
\hline $\mathrm{BF}$ & 49.67 & $<0.0001$ & 4.39 & 0.0035 & 6.80 & 0.0115 & 4.17 & 0.0048 & 5.48 & 0.0226 & 1.24 & NS \\
\hline FF & 24.00 & $<0.0001$ & 3.67 & 0.0097 & 4.44 & 0.0394 & 3.65 & 0.0100 & 4.22 & 0.0443 & 0.92 & NS \\
\hline PP & 36.87 & $<0.0001$ & 3.63 & 0.0102 & 1.87 & NS & 3.63 & 0.0103 & 1.87 & NS & 2.10 & NS \\
\hline OP & 45.42 & $<0.0001$ & 3.68 & 0.0096 & 4.22 & 0.0442 & 3.66 & 0.0099 & 4.14 & 0.0462 & 0.69 & NS \\
\hline \multicolumn{13}{|c|}{ Ecological indices } \\
\hline$F / B$ & 8.71 & 0.005 & 0.76 & NS & 0.48 & NS & 0.34 & NS & 1.19 & NS & 0.52 & NS \\
\hline NCR & 17.50 & 0.0001 & 0.66 & NS & 0.63 & NS & 0.39 & NS & 1.16 & NS & 0.63 & NS \\
\hline T & 55.27 & $<0.0001$ & 0.57 & NS & 0.78 & NS & 0.51 & NS & 0.53 & NS & 0.50 & NS \\
\hline$H^{\prime}$ & 618.16 & $<0.0001$ & 1.29 & NS & 22.40 & $<0.0001$ & 1.69 & NS & 23.27 & $<0.0001$ & 0.76 & NS \\
\hline$\lambda$ & 177.50 & $<0.0001$ & 0.93 & NS & 2.82 & NS & 1.79 & NS & 20.50 & $<0.0001$ & 0.41 & NS \\
\hline SR & 139.82 & $<0.0001$ & 0.36 & NS & 3.39 & NS & 1.25 & NS & 8.16 & 0.0062 & 0.45 & NS \\
\hline MI & 22.25 & $<0.0001$ & 1.74 & NS & 1.24 & NS & 2.71 & 0.0417 & 5.07 & 0.0292 & 1.84 & NS \\
\hline MMI & 12.18 & 0.001 & 1.27 & NS & 0.95 & NS & 2.20 & NS & 0.33 & NS & 0.51 & NS \\
\hline $\mathrm{El}$ & 9.75 & 0.0032 & 1.69 & NS & 5.78 & 0.0206 & 0.41 & NS & 0.01 & NS & 0.14 & NS \\
\hline SI & 22.56 & $<0.0001$ & 0.56 & NS & 1.66 & NS & 3.08 & 0.0253 & 11.82 & 0.0013 & 1.85 & NS \\
\hline
\end{tabular}

*SM: soil moisture; OM: organic matter; EC: electrical conductivity; TN: total number of nematodes; BF: bacterivores; FF: fungivores; PP: plantparasite nematodes; OP: omnivore-predator nematodes; F/B: fungivores/bacterivores ratio; NCR: nematode channel ratio T: trophic diversity; $H$ ': Shannon index; $\lambda$ : genus dominance; SR: species richness; Ml: maturity index; MMI: modified maturity index; El: enrichment index; SI: structure index. NS: no significant.

nematodes assigned by Bongers (1990) to the $i$-th nematode genus and $p i$ is the proportion of the genus in the nematode community (Yeates, 1994); (11) El, Enrichment Index is calculated as El $=100(e /(e+b))$, where $e$ is the abundance of individuals in guilds in the enrichment component weighted by their respective $k_{\mathrm{e}}$ values and $b$ is the abundance of individuals in the basal component weighted by their $k_{b}$ values (Ferris et al., 2001; 2004; Ferris \& Matute, 2003); (12) SI, Structure Index is calculated as $\mathrm{SI}=100(s /$ $(s+b))$, where $s$ is the abundance of individuals in the structure component weighted by their $k_{\mathrm{s}}$ values.

All obtained data were subjected to statistical analysis of variance (ANOVA) using the SAS model (GLM, Duncan's multiple range test and Pearson correlation coefficient) and were used to evaluate differences between separate means. CANOCO redundancy analysis (ter Braak \& Prentice 1996; ter Braak \& Smilauer 2002) were used to evaluate the relationship among nematode trophic groups, soil depths and environmental variables. Differences obtained at levels of $P<0.05$ were considered significant.

\section{Ethical Approval and/or Informed Consent}

This study is neither related to human nor animals use.

\section{Results}

\section{Soil physico-chemical properties}

Soil moisture reached a maximum value of $7.2 \%$ in the $0-10 \mathrm{~cm}$ soil layer at the playa site in the wet season, whereas a minimum value of $0.1 \%$ was found in the dry season in the 0 to $20 \mathrm{~cm}$ soil layer in the loessial plain area. Soil moisture in the playa area was significantly $(P<0.05)$ higher than that in the loessial plain area during the dry and wet seasons (Table 1). Moreover, the univariate 


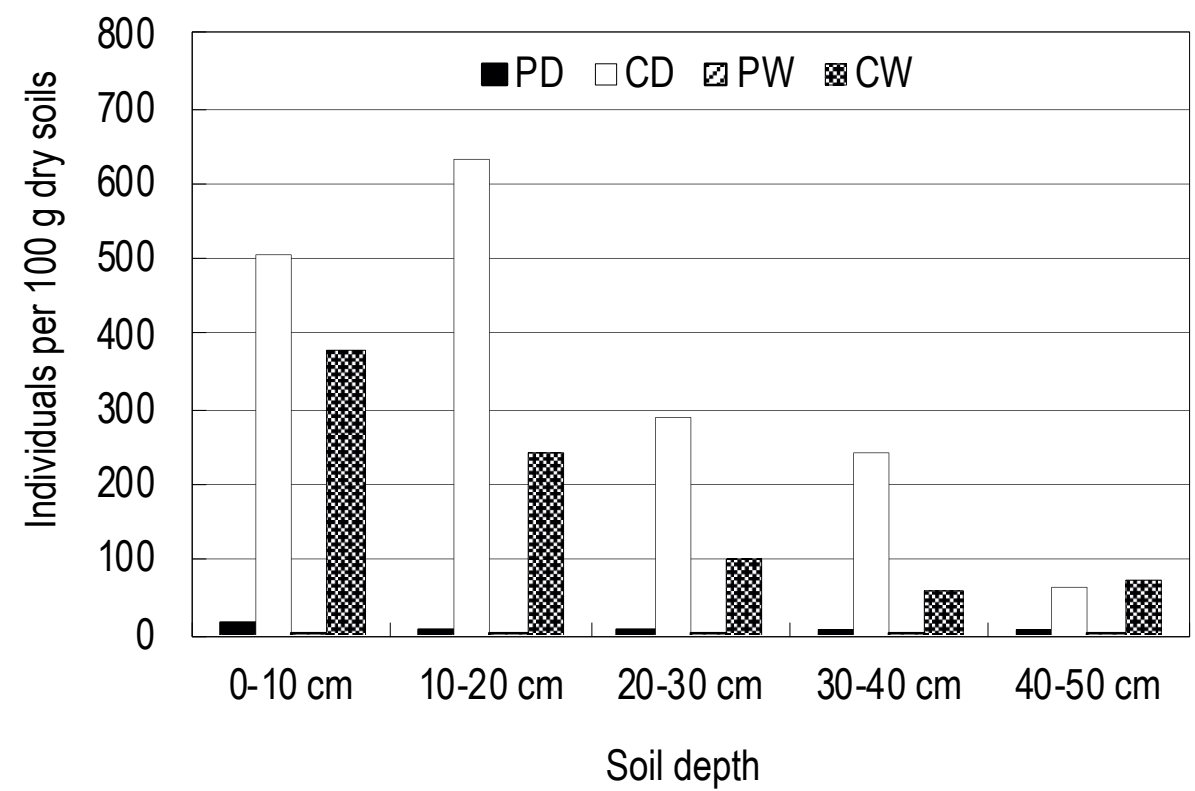

Fig. 1. Vertical distribution of total number of nematode at five soil depths in the playa and loessial plain areas during the dry and wet seasons. PD-playa area during the dry season; PW-playa area during the wet season; CD-loessial plain area during the dry season; CW-loessial plain area during the wet season.

analysis elucidated a significant $(P<0.001)$ effect of the different factors, such as: sampling location, depth, season and interaction between them, except the combination of three of the factors (Table 2).

Soil organic matter content was found to reach a maximum value in the $0-10 \mathrm{~cm}$ layer in the playa site under dry the season and a minimum in the $20-40 \mathrm{~cm}$ soil layer in the loessial plain area during the wet season. Moreover, general high values were in the playa soil samples (Table 1). Significant difference in soil organic matter content were found by location $(P<0.0001)$ and depth $(P<$ 0.01 ), rather than by seasonality (Table 2 ).

Soil electrical conductivity was found to follow the soil organic matter trend, with significantly $(P<0.0001)$ (Table 1$)$ higher values in the playa area during the dry season than that in the loessial plain area during both seasons. Soil electrical conductivity was also significantly influenced by location $(P<0.0001)$ and depth $(P<0.01)$ (Table 2).

\section{Total number of nematode}

Total number of nematode in the playa area ranged from 1 to 15 individuals per $100 \mathrm{~g}$ dry soil, while total number of nematode in the loessial plain area was many fold higher, ranging from 60 to 631 individuals per $100 \mathrm{~g}$ dry soil and resulting in significant $(P<$ 0.0001 ) differences between the sampling sites (Fig. 1). Moreover, total nematode abundance of every soil layer in the loessial plain area was significnatly $(P<0.0001)$ higher than that in the playa area during the dry and wet seasons. The upper soil layers were represented by a higher nematode abundance and the number of nematode had gradually decreasing trend with soil depths increasing at both sampling sites and seasons. In general, total number of soil free living nematode was significantly affected by sampling locations $(P<0.0001)$, depths $(P<0.001)$ and seasons $(P<0.01)$ on (Table 2). Total soil free living nematode was found to be significantly negatively correlated with soil moisture, soil organic matter content and electrical conductivity, respectively (Table 3).

\section{Nematode trophic groups}

The general pattern obtained for the changes in total soil free living nematode were found to be reflected in the trophic group abundance. Bacterivores were found to be the dominant trophic group in the present study, and they were significantly greater $(P<0.05)$ in the loessial plain area than that in the playa area in each layer during the dry and wet seasons. In the playa and loessial plain area, bacterivores in the upper soil layer $(0-10 \mathrm{~cm})$ was greater than in the other layers during the dry and wet seasons (Fig. 2). In general, bacterivores were significantly affected by sampling locations $(P<0.0001)$, depths $(P<0.01)$ and seasons $(P<0.05)$ (Table 2). Bacterivores exhibited a significant negative correlation with soil moisture and electrical conductivity (Table 3).

Fungivores were found in lower numbers, whereas the pattern of their behavior was found to replicate that of the bacterivores, with a relatively higher population size in the loessial plain area than in the playa area in all sampling depths and season (Fig. 2). In the upper $0-10 \mathrm{~cm}$ soil layer in the loessial plain area, the fungivores had a higher abundance during the dry and wet season. Furthermore, the overall data revealed that the sampling locations $(P<0.0001)$, depths $(P<0.01)$ and seasons $(P<0.05)$ significantly effected on their number (Table 2). Fungivores manifested a significant negative correlation with soil moisture and electrical conductivity (Table 3). 
Table 3. Correlation coefficients between soil properties and soil nematode indices.

\begin{tabular}{|c|c|c|c|}
\hline Index & SM & OM & EC \\
\hline $\mathrm{TN}^{\dagger}$ & $-0.44^{+* *+*}$ & $-0.23^{*}$ & $-0.51^{\text {tot }}$ \\
\hline BF & $-0.41^{1+* x}$ & NS & $-0.48^{*+* x}$ \\
\hline FF & $-0.33^{* *}$ & NS & $-0.37^{t+4 x}$ \\
\hline PP & $-0.36^{* *}$ & $-0.2^{*}$ & $-0.44^{*+* x}$ \\
\hline $\mathrm{OP}$ & $-0.43^{+1+x}$ & $-0.25^{*}$ & $-0.48^{*+*+}$ \\
\hline$F / B$ & $-0.28^{*}$ & NS & NS \\
\hline NCR & $0.36^{* *}$ & NS & $0.35^{* *}$ \\
\hline $\mathrm{T}$ & $-0.52^{4+* t}$ & $-0.44^{*+* x}$ & $-0.58^{t+k x}$ \\
\hline $\mathrm{H}^{\prime}$ & $-0.77^{t+1+x}$ & $-0.54^{*+* x}$ & $-0.78^{t+1 x}$ \\
\hline$\lambda$ & $0.74^{+*+x}$ & $0.47^{+* * *}$ & $0.70^{*+4}$ \\
\hline SR & $-0.6^{*+* *}$ & $-0.57^{* * * *}$ & $-0.72^{*+1+}$ \\
\hline MI & $-0.56^{*+* *}$ & $-0.42^{* * * *}$ & $-0.42^{*+*+}$ \\
\hline MMI & $-0.40^{+* * *}$ & $-0.35^{* *}$ & $-0.32^{* *}$ \\
\hline El & NS & NS & $-0.39^{* *}$ \\
\hline SI & $-0.58^{+t+x}$ & $-0.44^{* * * *}$ & $-0.47^{4+* x}$ \\
\hline
\end{tabular}

Plant-parasitic nematodes were the least trophic group (Fig. 2). Plant-parasitic nematodes were significantly affected by sampling locations $(P<0.0001)$ and depths $(P<0.05)$ (Table 2$)$ and significantly negatively correlated with soil moisture, soil organic matter content and electrical conductivity (Table 3).

Omnivores-predators were found to follow bacteria-feeding and fungi-feeding trophic groups, with a higher abundance in the loessial plain area and in the $0-20 \mathrm{~cm}$ soil layer (Fig. 2). Omnivores-predators were significantly influenced by sampling locations $(P<0.0001)$, depths $(P<0.01)$ and seasons $(P<0.05)$ (Table 2). Omnivores-predators were significantly negatively correlated with soil moisture, soil organic matter content and electrical conductivity (Table 3).

RDA analysis revealed that BF and OP were mainly distributed within the $0-10 \mathrm{~cm}$ depth and PP mainly in the $10-20 \mathrm{~cm}$ and 20 $-30 \mathrm{~cm}$ depths in the playa area during the dry season (Fig. 3). BF and PP were mainly distributed in the $0-10 \mathrm{~cm}$ depth in the playa area during the wet season. All trophic group of nematodes were mainly distributed within the $0-10 \mathrm{~cm}, 10-20 \mathrm{~cm}$ and $20-30$ $\mathrm{cm}$ in the loessial plain area during the dry season, and correlated positively with soil organic matter content and negatively with soil moisture and electrical conductivity. However, the trophic group of nematodes was mainly distributed within the $0-10 \mathrm{~cm}$ and $10-20 \mathrm{~cm}$ in the loessial plain area during the wet season, and positively correlated with soil organic matter content, soil moisture and electrical conductivity.

\section{Nematode taxa}

Total of 55 genera were observed, including 19 bacterivores, 10 fungivores, 12 plant-parasites, and 14 omnivore-predators (Table 4). Total of thirteen genera (including 6 bacterivores, 1 fungivores, 5 plant-parasites, and 1 omnivore-predators) were found in the playa area, while total of fifty-five genera (including 19 bacterivores, 10 fungivores, 12 plant-parasites, and 14 omnivore-predators) were found in the loessial plain area. Acrobeloides, Metateratocephalus and Acrobeles were the dominant genera in the playa area and were mainly present to the $0-20 \mathrm{~cm}$ depth, while Acrobeles, Metateratocephalus, Cephalobus, Aphelenchoides, Chiloplacus and Acrobeloides were the dominant genera in the loessial plain area and were also mainly present to the $0-20 \mathrm{~cm}$ depth.

\section{Nematode ecological indices}

F/B values at every soil layer in the loessial plain area were higher compared with the playa area during the dry and wet seasons (Table 5). Significant difference in the F/B values was found between locations $(P<0.01)$, but no significant differences were observed between depths and between seasons (Table 2). F/B values significantly negatively correlated with soil moisture (Table 3).

NCR values at every soil layer in the playa area were higher contrasted with the loessial plain area during the dry and wet seasons (Table 5). Significant difference in the NCR values was found between locations $(P<0.001)$, but no significant differences were 
A

Individuals per $100 \mathrm{~g}$ dry soil

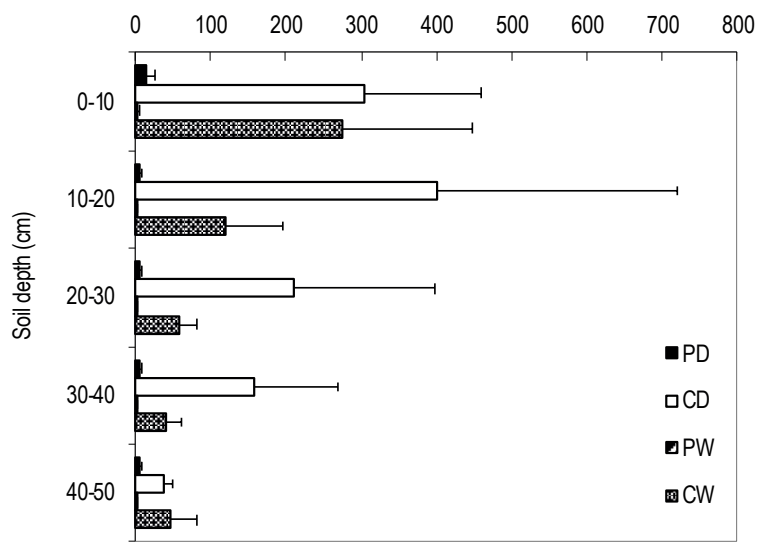

B

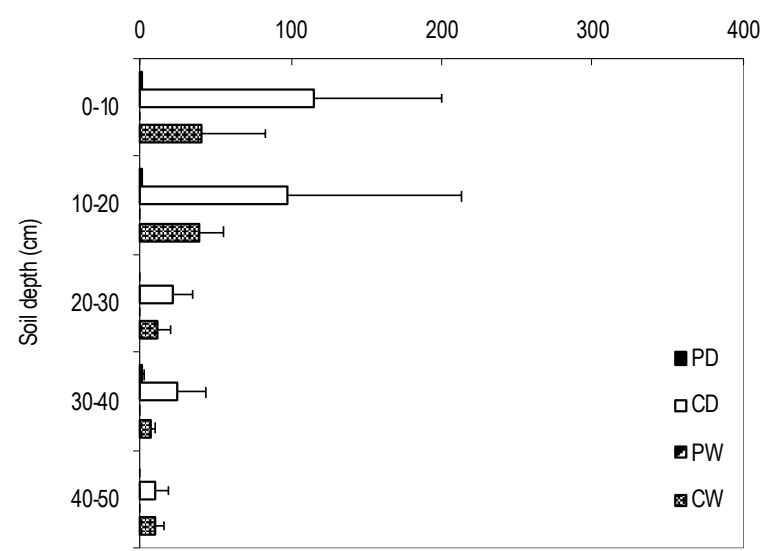

C

Individuals per $100 \mathrm{~g}$ dry soil

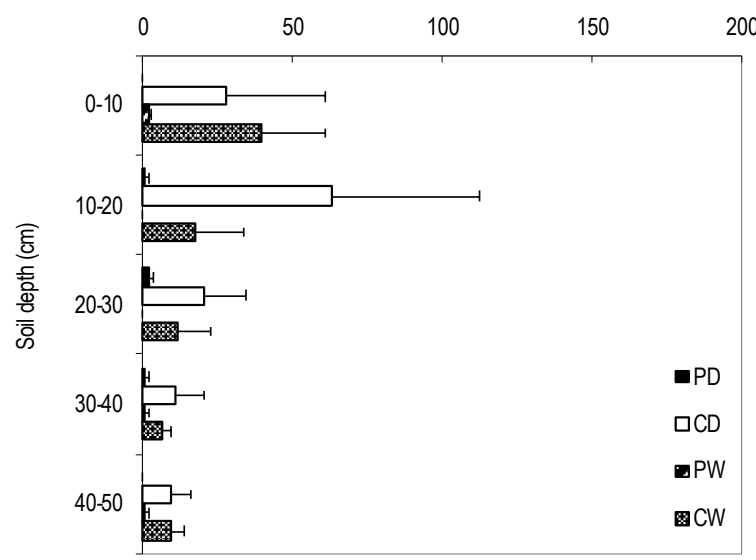

D

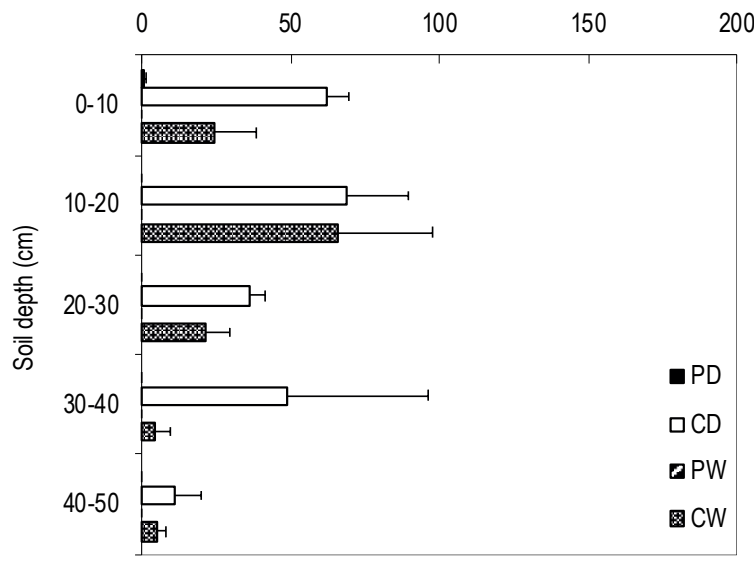

Fig. 2. Vertical distribution of nematode trophic groups at five soil depths in the playa and loessial plain areas during the dry and wet seasons. A. bacterivores, B. fungivores, C. plant parasites, D. omnivores-predators. PD-playa area during the dry season; PW-playa area during the wet season; CD- loessial plain area during the dry season; CW- loessial plain area during the wet season.

observed between depths and between seasons (Table 2). NCR values significantly positively correlated with soil moisture and electrical conductivity (Table 3).

$\mathrm{T}$ values at every soil layer in the loessial plain area were higher compared with the playa area during the dry and wet seasons (Table 5). Significant sampling locations effect was found on the $T$ values $(P<0.0001)$, but no significant differences were observed between depths and between seasons (Table 2). T values correlated significantly negatively with soil moisture, soil organic matter content and electrical conductivity (Table 3).

$H^{\prime}$ values at every soil layer in the loessial plain area were higher than that in the playa area during the dry and wet seasons (Table 5). Significant sampling locations and seasons effects were found on the H' values $(P<0.0001)$, but no significant difference in $\mathrm{H}^{\prime}$ values was observed between depths (Table 2). H' values significantly negatively correlated with soil moisture, soil organic matter content and electrical conductivity (Table 3).
The $\lambda$ values at every soil layer in the loessial plain area were lower compared with the playa area during the dry and wet seasons (Table 5). Significant sampling location effect was found on the $\lambda$ values $(P<0.0001)$, but no significant differences in the $\lambda$ values were observed between depths and between seasons. Significant interaction effect of locations and seasons $(P<0.0001)$ was observed in the $\lambda$ values (Table 2 ). The $\lambda$ values significantly positively correlated with soil moisture, soil organic matter content and electrical conductivity (Table 3).

SR values at every soil layer in the loessial plain area were higher contrasted with the playa area during the dry and wet seasons (Table 5). Significant sampling location effect was found on the SR values $(P<0.0001)$, but no significant differences in the SR values were observed between depths and between seasons. Significant interaction effect of locations and seasons $(P<0.01)$ was detected in the SR values (Table 2). SR values significantly negatively correlated with soil moisture, soil organic matter content and electrical 
Table 4. Number of soil nematode (individuals per $100 \mathrm{~g}$ dry soils) across all soil layers in the playa and loessial plain areas during the dry and wet seasons.

\begin{tabular}{|c|c|c|c|c|c|}
\hline \multirow{2}{*}{ Genus } & \multirow{2}{*}{$\begin{array}{c}c-p^{*} \\
\text { values }\end{array}$} & \multicolumn{2}{|c|}{ Dry season } & \multicolumn{2}{|c|}{ Wet season } \\
\hline & & playa & loessial plain & playa & loessial plain \\
\hline \multicolumn{6}{|l|}{ Bacterivores $^{* *}$} \\
\hline Acrobeles & 2 & $0.8^{* * *}$ & 74.9 & 0.3 & 42.3 \\
\hline Acrobeloides & 2 & 2.7 & 24.4 & 0.3 & 07.1 \\
\hline Alaimus & 4 & 0.0 & 00.0 & 0.0 & 00.1 \\
\hline Cephalobus & 2 & 0.5 & 32.3 & 0.0 & 15.5 \\
\hline Cervidellus & 2 & 0.0 & 04.8 & 0.0 & 00.0 \\
\hline Chambersiella & 2 & 0.0 & 02.6 & 0.0 & 00.5 \\
\hline Chiloplacus & 2 & 0.0 & 23.9 & 0.1 & 14.4 \\
\hline Diploscapter & 1 & 0.0 & 00.0 & 0.1 & 02.9 \\
\hline Eucephalobus & 2 & 0.0 & 00.9 & 0.0 & 02.0 \\
\hline Mesorhabditis & 1 & 0.0 & 03.1 & 0.0 & 00.0 \\
\hline Metateratocephalus & 3 & 3.0 & 46.8 & 0.0 & 20.7 \\
\hline Monhystera & 2 & 0.0 & 00.0 & 0.0 & 00.1 \\
\hline Panagrobelus & 1 & 0.0 & 00.0 & 0.0 & 00.9 \\
\hline Panagrolaimus & 1 & 0.0 & 01.6 & 0.0 & 00.5 \\
\hline Plectus & 2 & 0.0 & 03.4 & 0.0 & 00.1 \\
\hline Protorhabditis & 1 & 0.0 & 00.0 & 0.0 & 00.1 \\
\hline Rhabditis & 1 & 0.0 & 01.9 & 0.0 & 00.4 \\
\hline Tylocephalus & 2 & 0.0 & 00.0 & 0.0 & 01.0 \\
\hline Wilsonema & 2 & 0.0 & 01.3 & 0.0 & 00.0 \\
\hline \multicolumn{6}{|l|}{ Fungivores } \\
\hline Aphelenchoides & 2 & 0.4 & 38.2 & 0.0 & 07.8 \\
\hline Aphelenchus & 2 & 0.0 & 08.6 & 0.0 & 09.2 \\
\hline Aprutides & 2 & 0.0 & 00.0 & 0.0 & 00.2 \\
\hline Diphtherophora & 3 & 0.0 & 00.0 & 0.0 & 00.7 \\
\hline Ditylenchus & 2 & 0.0 & 00.0 & 0.0 & 00.1 \\
\hline Nothotylenchus & 2 & 0.0 & 01.4 & 0.0 & 00.5 \\
\hline Panaphelenchus & 2 & 0.0 & 00.0 & 0.0 & 00.5 \\
\hline Tylencholaimellus & 4 & 0.0 & 03.2 & 0.0 & 02.2 \\
\hline Tylencholaimus & 4 & 0.0 & 02.5 & 0.0 & 00.7 \\
\hline Belonolaimus & 3 & 0.0 & 00.0 & 0.0 & 00.9 \\
\hline \multicolumn{6}{|l|}{ Plant-parasites } \\
\hline Filenchus & 2 & 0.0 & 01.4 & 0.0 & 01.2 \\
\hline Helicotylenchus & 3 & 0.4 & 01.1 & 0.0 & 00.0 \\
\hline Hoplolaimus & 3 & 0.0 & 02.1 & 0.0 & 01.4 \\
\hline Longidorus & 5 & 0.0 & 05.5 & 0.0 & 00.1 \\
\hline Paratylenchus & 2 & 0.0 & 00.0 & 0.0 & 01.6 \\
\hline Pratylenchus & 3 & 0.0 & 02.1 & 0.0 & 02.9 \\
\hline Telotylenchus & 3 & 0.0 & 01.3 & 0.1 & 02.8 \\
\hline
\end{tabular}




\begin{tabular}{llllll} 
Tetylenchus & 3 & 0.0 & 01.6 & 0.1 & 02.2 \\
Tridorus & 4 & 0.0 & 00.0 & 0.0 & 00.2 \\
$\begin{array}{l}\text { Tylenchorhynchus } \\
\text { Tylenchus }\end{array}$ & 3 & 0.0 & 07.7 & 0.1 & 03.2 \\
$\begin{array}{l}\text { Xiphinema } \\
\text { Omnivores-predators }\end{array}$ & 2 & 0.1 & 00.6 & 0.2 & 00.4 \\
Aporcelaimellus & 5 & 0.0 & 02.8 & 0.0 & 00.0 \\
Aporcelaimus & 5 & 0.0 & 01.1 & 0.0 & 02.5 \\
Clarkus & 5 & 0.1 & 12.8 & 0.0 & 04.4 \\
Discolaimium & 4 & 0.0 & 00.5 & 0.0 & 0.0 \\
Discolaimus & 5 & 0.0 & 00.0 & 0.0 & 00.2 \\
Dorylaimellus & 5 & 0.0 & 03.2 & 0.0 & 06.6 \\
Dorylaimoides & 5 & 0.0 & 07.6 & 0.0 & 01.4 \\
Dorylaimus & 4 & 0.0 & 00.7 & 0.0 & 00.0 \\
Eudorylaimus & 4 & 0.0 & 03.0 & 0.0 & 00.0 \\
Labronema & 4 & 0.0 & 06.3 & 0.0 & 00.0 \\
Mesodorylaimus & 4 & 0.0 & 03.7 & 0.0 & 03.8 \\
Mononchus & 5 & 0.0 & 05.4 & 0.0 & 00.0 \\
Nygolaimus & 4 & 0.0 & 00.9 & 0.0 & 00.0 \\
Thonus & 5 & 0.0 & 00.0 & 0.0 & 00.8 \\
\hline
\end{tabular}

${ }^{*} c-p$ values, characterized by life history characteristics, are adapted from Bongers (1990).

** Trophic groups according to Yeates et al. (1993).

***Means from four replicates.

conductivity (Table 3).

Ml values at every soil layer in the loessial plain area were higher compared with the playa area during the wet season (Table 5). Significant sampling locations effect was found on the MI values $(P<0.0001)$, but no significant differences in the Ml values were observed between depths and between seasons. Significant interaction effects of locations and depths, locations and seasons $(P<$ 0.05 ) were detected in the MI values (Table 2). MI values significantly negatively correlated with soil moisture, soil organic matter content and electrical conductivity (Table 3).

MMI values at every soil layer in the loessial plain area were higher contrasted with the playa area, except the $30-40 \mathrm{~cm}$ layer during the wet season (Table 5). Significant sampling location effect was found on the MMI values $(P<0.01)$, but no significant differences in the MMI values were observed between depths and between seasons (Table 2). MMI values significantly negatively correlated with soil moisture, soil organic matter content and electrical conductivity (Table 3).

El values in every soil layer in the loessial plain area were higher compared with the playa area (except the $0-10 \mathrm{~cm}$ layer during the wet season) during the dry and the wet seasons (Table 5). Significant differences in the El values were found between locations $(P<0.01)$ and between seasons $(P<0.05)$, but no significant difference was observed between depths (Table 2). El values significantly negatively correlated with electrical conductivity (Table 3).
SI values in every soil layer in the loessial plain area were higher contrasted with the playa area (except for the $0-10 \mathrm{~cm}$ and 40 $-50 \mathrm{~cm}$ layers during the dry season) during the dry and wet seasons (Table 5). Significant difference in the SI values was found between locations $(P<0.0001)$, but no significant differences were observed between depths and between seasons (Table 2). Significant interaction effects of locations and depths $(P<0.05)$, locations and seasons $(P<0.01)$ were detected in the SI values. SI values significantly negatively correlated with soil moisture, soil organic matter content and electrical conductivity (Table 3).

Integrating all the data using RDA (Fig. 3) for each of the sampling sites and seasons and soil depths indicated a strong effect between the dry (Fig. $3 \mathrm{~A}, \mathrm{~B}$ ) and wet periods (Fig. $3 \mathrm{C}, \mathrm{D}$ ) of each treatment. The relatively higher values of soil moisture (SM) during the wet period were found to explain the significant difference between the sampling sites. In the playa area (Fig. 3A, B) the SM was found to move to deeper layers, whereas the SM in loessial plain area remained close to the upper soil layer (Fig. 3 C, D). Different behavior of SM between the two sites explain the importance of soil pedological characteristics. The second variable known to play an important role in basic food source availability is the OM whose behavior was found to remain stable in the upper soil layers in both cases. These main variables were found to have the greatest significant effect on the soil free living nematode community abundance, distribution and trophic groups (Fig. 3), where 
Table 5. Nematode ecological indices in different sampling sites, depths and seasons.

\begin{tabular}{|c|c|c|c|c|c|c|c|c|c|c|}
\hline \multirow{3}{*}{ Index } & \multicolumn{10}{|c|}{ Sampling depths (cm) } \\
\hline & \multicolumn{2}{|c|}{$0-10$} & \multicolumn{2}{|c|}{$10-20$} & \multicolumn{2}{|c|}{$20-30$} & \multicolumn{2}{|c|}{$30-40$} & \multicolumn{2}{|c|}{$40-50$} \\
\hline & Playa & Control & Playa & Control & Playa & Control & Playa & Control & Playa & Control \\
\hline \multicolumn{11}{|c|}{ Dry season } \\
\hline $\mathrm{F} / \mathrm{B}^{*}$ & $0.25 b^{* *}$ & $0.35 a$ & $0.13 a$ & $0.20 \mathrm{a}$ & $0.00 \mathrm{~b}$ & $0.19 a$ & $0.13 a$ & $0.18 a$ & $0.00 \mathrm{~b}$ & $0.30 \mathrm{a}$ \\
\hline NCR & $0.88 a$ & $0.74 b$ & $0.92 a$ & $0.84 a$ & $1.00 \mathrm{a}$ & $0.85 b$ & $0.90 \mathrm{a}$ & $0.86 a$ & $1.00 \mathrm{a}$ & $0.80 \mathrm{~b}$ \\
\hline $\mathrm{T}$ & $1.29 \mathrm{~b}$ & $2.20 \mathrm{a}$ & $1.42 b$ & $2.37 a$ & $1.23 b$ & $2.28 \mathrm{a}$ & $1.44 b$ & $2.25 \mathrm{a}$ & $1.00 \mathrm{~b}$ & $2.50 \mathrm{a}$ \\
\hline$H^{\prime}$ & $0.92 b$ & $2.23 a$ & $0.78 b$ & $2.32 a$ & $0.71 b$ & $2.12 a$ & $0.95 b$ & $2.23 a$ & $0.49 b$ & $2.10 \mathrm{a}$ \\
\hline$\lambda$ & $0.44 a$ & $0.14 b$ & $0.54 a$ & $0.13 b$ & $0.55 a$ & $0.16 b$ & $0.41 \mathrm{a}$ & $0.14 b$ & $0.66 a$ & $0.14 b$ \\
\hline SR & $0.78 b$ & $1.89 a$ & $0.77 b$ & $2.07 a$ & $0.61 b$ & $1.99 a$ & $0.88 b$ & $2.19 a$ & $0.46 b$ & $2.12 a$ \\
\hline MI & $2.43 a$ & $2.25 b$ & $2.25 b$ & $2.81 \mathrm{a}$ & $2.17 b$ & $2.83 a$ & $2.35 b$ & $2.86 \mathrm{a}$ & $2.71 \mathrm{a}$ & $2.58 b$ \\
\hline MMI & $2.43 a$ & $2.35 \mathrm{a}$ & $2.25 b$ & $2.85 a$ & $2.48 \mathrm{~b}$ & $2.90 \mathrm{a}$ & $2.39 b$ & $2.86 a$ & $2.71 \mathrm{a}$ & $2.66 \mathrm{a}$ \\
\hline El & $8.25 b$ & $34.75 a$ & $8.33 a$ & $14.75 a$ & $0.00 \mathrm{~b}$ & $11.25 a$ & $10.50 \mathrm{a}$ & $15.50 a$ & $0.00 \mathrm{~b}$ & $22.50 \mathrm{a}$ \\
\hline SI & $54.50 a$ & $41.00 \mathrm{~b}$ & $25.00 b$ & $70.00 a$ & $23.00 \mathrm{~b}$ & $71.25 a$ & $49.50 \mathrm{~b}$ & $73.75 a$ & $83.25 a$ & $62.25 b$ \\
\hline \multicolumn{11}{|c|}{ Wet season } \\
\hline$F / B$ & $0.00 \mathrm{~b}$ & $0.28 a$ & $0.00 \mathrm{~b}$ & $0.38 a$ & $0.00 \mathrm{~b}$ & $0.19 a$ & $0.00 \mathrm{~b}$ & $0.19 a$ & $0.00 \mathrm{~b}$ & $0.37 a$ \\
\hline NCR & $1.00 \mathrm{a}$ & $0.82 b$ & $1.00 \mathrm{a}$ & $0.73 b$ & $1.00 \mathrm{a}$ & $0.84 b$ & $1.00 \mathrm{a}$ & $0.85 b$ & $1.00 \mathrm{a}$ & $0.78 \mathrm{~b}$ \\
\hline $\mathrm{T}$ & $1.20 \mathrm{~b}$ & $2.08 a$ & $1.00 \mathrm{~b}$ & $2.92 \mathrm{a}$ & $1.00 \mathrm{~b}$ & $2.49 a$ & $1.00 \mathrm{~b}$ & $1.98 \mathrm{a}$ & $1.00 \mathrm{~b}$ & $2.33 a$ \\
\hline $\mathrm{H}^{\prime}$ & $0.45 b$ & $2.42 a$ & $0.00 \mathrm{~b}$ & $2.32 a$ & $0.00 \mathrm{~b}$ & $2.15 a$ & $0.00 \mathrm{~b}$ & $2.09 a$ & $0.00 \mathrm{~b}$ & $2.05 a$ \\
\hline$\lambda$ & $0.71 \mathrm{a}$ & $0.20 \mathrm{~b}$ & $1.00 \mathrm{a}$ & $0.11 b$ & $1.00 \mathrm{a}$ & $0.17 b$ & $1.00 \mathrm{a}$ & $0.15 b$ & $1.00 \mathrm{a}$ & $0.12 b$ \\
\hline SR & 0.44 & 1.91 & 0.00 & 2.39 & 0.00 & 2.16 & 0.00 & 2.48 & 0.00 & 2.88 \\
\hline MI & $1.75 b$ & $2.42 a$ & $2.00 \mathrm{~b}$ & $2.95 \mathrm{a}$ & $2.00 \mathrm{~b}$ & $2.84 a$ & $2.00 \mathrm{~b}$ & $2.40 a$ & $2.00 \mathrm{~b}$ & $2.39 a$ \\
\hline MMI & $2.13 b$ & $2.47 a$ & $2.00 \mathrm{~b}$ & $2.93 a$ & $2.00 \mathrm{~b}$ & $2.85 a$ & $2.50 \mathrm{a}$ & $2.46 a$ & $2.50 \mathrm{a}$ & $2.53 a$ \\
\hline El & $40.00 \mathrm{a}$ & $26.00 \mathrm{~b}$ & $0.00 \mathrm{~b}$ & $20.25 a$ & $0.00 \mathrm{~b}$ & $23.50 \mathrm{a}$ & $0.00 \mathrm{~b}$ & $29.25 a$ & $0.00 \mathrm{~b}$ & $32.50 \mathrm{a}$ \\
\hline SI & $0.00 \mathrm{~b}$ & $55.00 a$ & $0.00 \mathrm{~b}$ & $76.75 a$ & $0.00 \mathrm{~b}$ & $74.75 a$ & $0.00 \mathrm{~b}$ & $55.25 a$ & $0.00 \mathrm{~b}$ & $51.75 a$ \\
\hline
\end{tabular}

in the playa area the OM was found to have a great effect on TN compared with the loessial plain area. Redundancy analysis reflected that the nematode community mainly distributed in the upper soil layers $(0-20 \mathrm{~cm})$ under the playa and loessial plain area.

\section{Discussion}

The playa and loessial plain area (as control) are two main geomorphological units in the inter-sand dune area in the North-Western Negev desert (Kidron et al., 2008). Soil moisture, organic matter content and electrical conductivity in the playa area were higher than in the loessial plain area, reflecting the pedological differences and their effect on the soil biota community (Pen-Mouratov et al., 2011; Yu et al., 2012). The playa area represents a flat bare soil surface, scattered within the interdunes, with roughly no vegeta- tion (perennial, microbiotic crusts) cover and very few tubules and holes, reflecting a rigorous soil environment, compared with the loessial plain area which is covered by a thin microbiotic crust and a vegetation cover which moderates the harsh abiotic environment (Kidron, 2001). Although there had high soil moisture and organic matter content in the playa area, high salt content may harm to soil biological community (Liang and Steinberger, 2001; Shamir \& Steinberger, 2007), as revealed that there has less biological community in the playa area compared with loessial plain area. Our results which total number of nematode at every soil layer in the playa area was significantly less than in the loessial plain area during the dry and wet season testified this truth. These results manifested the aboveground and belowground components in the terrestrial ecosystems could interact. Total number of nematode in the present study were higher than that $(4-200$ individuals per 

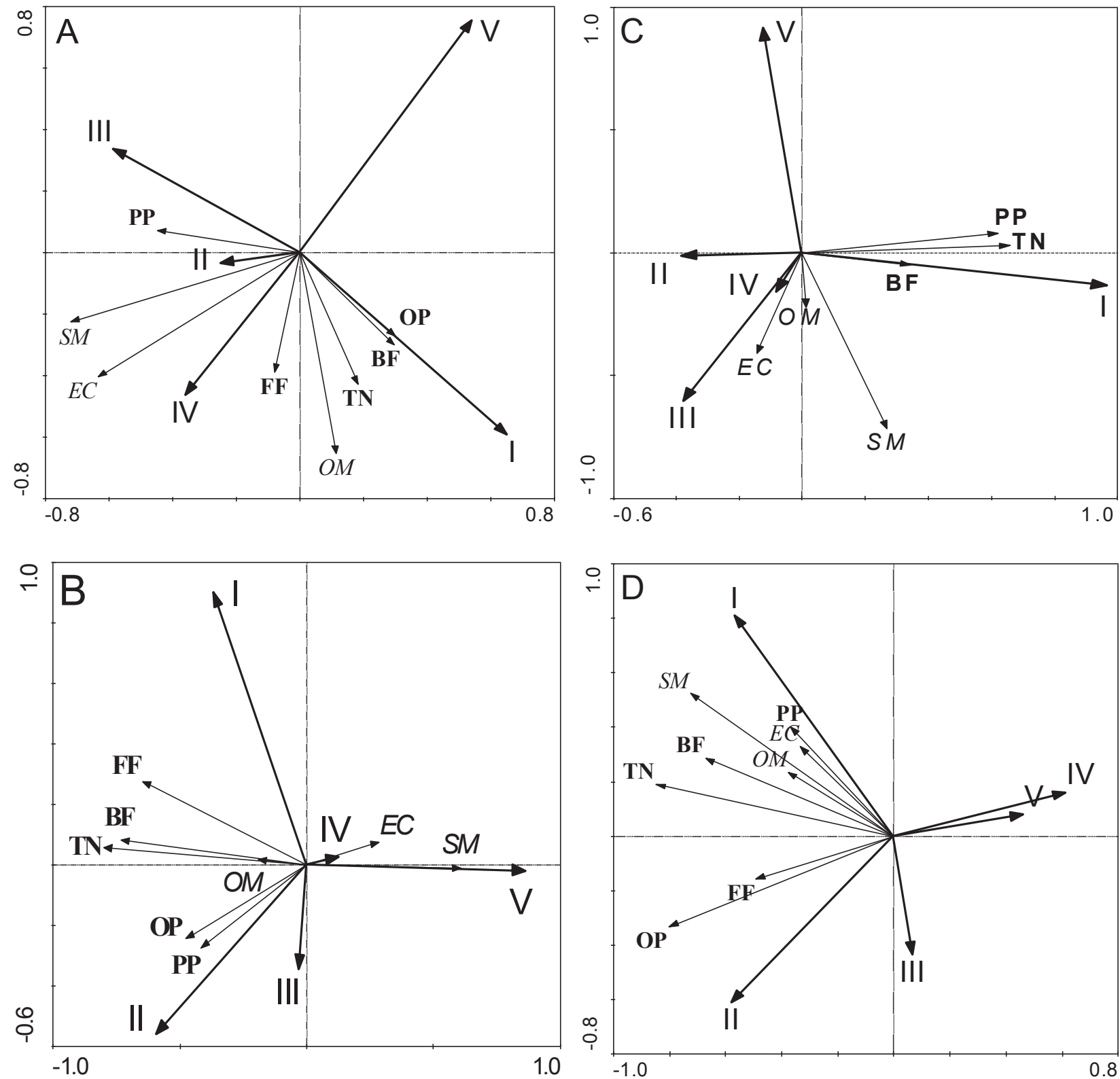

Fig. 3. Redundancy analysis (RDA) of soil moisture (SM), soil organic content (OM), electrical conductivity (EC), total number of nematode (TN), bacterivores (BF), fungivores (FF), plant - parasite nematode (PP) and omnivore - predator nematode (OP) with reference to different soil depths in the playa and loessial plain area during the dry and wet seasons. I, II, III, IV, V denote $0-10 \mathrm{~cm}, 10-20 \mathrm{~cm}, 20-30 \mathrm{~cm} 30-40 \mathrm{~cm}$ and $40-50 \mathrm{~cm}$ soil depths; A, playa area during the dry season; B, loessial plain area during the dry season; C, playa area during the wet season; $D$, loessial plain area during the wet season.

$100 \mathrm{~g}$ dry soils) in the horqin sandy land, Northeast China (Jiang et al., 2007), yet was similar to the result $(0-675$ individuals per $100 \mathrm{~g}$ dry soils) in in the Tehuacán Desert, Mexico (Pen-Mouratov et al., 2008b). Total number of nematode had the gradual decreasing trends with soil depths, which could reflect the stratification of their food resources. Zhang et al. (2010) also observed the similar trend in the stable sand dune system. Pen-Mouratov et al. (2008b) found that total number of nematode was the highest at $0-10 \mathrm{~cm}$ sampling soil layer in the Tehuacán Desert.
Bacterivores were the most dominant trophic group in this study, which was consistent with the findings of Rahman et al. (2009) and Zhang et al. (2009). Nevertheless, this differed from the result reported by Wall et al. (2002), who found that omnivores were the dominant trophic group followed by bacterivores in a sand dune coastal system at the Tay River. This reflected that the differences of soil environment and plant cover between terrestrial and coastal sand dunes. Plant parasites were the most abundant trophic group near plant soils in the Tehuacán Desert, Mexico (Pen-Mouratov et 
al., 2008b). Plant parasitic nematodes were the most dominant trophic groups in the wheat field in North China Plain (Hu \& Qi, 2013). Bacterivores and fungivores at every soil layer in the loessial plain area were higher than that in the playa area during the dry and wet seasons, which revealed that there had little microbial community in the playa area in contrast to the loessial plain area. In the present study plant-parasitic nematodes were the least trophic group, and Pen-Mouratov et al. (2011) also reported similar results. Omnivores-predators in the in the sandy biological crust area were higher than that in the playa area (Pen-Mouratov et al., 2011), which supported our findings. All nematode trophic groups were significantly influenced by sampling sites and depths (Pen-Mouratov et al., 2008b), as also supported our results.

Total 55 nematode genera were observed in all soil samples, which was higher than the taxa of nematode reported by Zhang et al. $(2007 ; 2010)$ in terrestrial sand dune system of China. But it was lower than the taxa of nematode reported by Wall et al. (2002) in sand dune system at the mouth of the river Tay. Acrobeles was the predominant genus, which was similar to the result from Danish sand dunes (Bussau, 1990) and from horqin sandy land in China (Jiang et al., 2007, Zhang et al., 2010). Pen-Mouratov et al. (2008a) also reported the similar results, which found that Acrobeles was dominant genus in the Negev Desert, Israel. However, Wall et al. (2002) reported that dorylaimids was dominant taxa in the sand dune soils of river. Dorylaimus was the most abundant in the inter plant soil spaces in the Tehuacán Desert, Mexico (Pen-Mouratov et al., 2008b). Prodorylaimus was the predominant genus in the rice-wheat cropping system of central China (Hu et al., 2018).

Nematode ecological indices can be used to estimate soil nematode community structure and composition (Yeates \& Bongers, 1999). Ecological indexes are known to be a useful tool for helping differentiate between sampling depths and sites effect. Jiang et al. (2007) found that different treatment significantly effected on the values of all ecological indices, whereas sampling depths had no effect on nematode ecological indices. Zhang et al. (2010) reported that significant depth effects were found in the values of $\mathrm{H}^{\prime}, \lambda$, SR. Similarly, Pen-Mouratov et al. (2008b) reported that values of $\mathrm{F} / \mathrm{B}, \mathrm{T}, \mathrm{H}^{\prime}, \mathrm{Ml}$ had significantly different between soil layers.

Fungivore/bacterivore ratio $(F / B)$ in the loessial plain area was higher than that in the playa area, which manifested that there had much more fungi community in the loessial plain area. Mean value of $F / B$ was higher in the wet season under the loessial plain area than in the dry season, which showed that there had much more fungi community in the wet season in contrast to the dry season. The results reported by Yu et al. (2012) supported this findings. Nematode channel ratio (NCR) reflects the soil bacterial or fungi decomposition pathway in the soil detrital food webs (Ruess, 2003). NCR values in the playa area were higher compared with loessial plain area, which manifested that bacterial decomposition pathway was predominant in the playa area. NCR values significantly negatively correlated with soil moisture and electrical con- ductivity in the Horqin Sandy Land of China (Zhang et al., 2007), which was inconsistent with the present study.

Trophic diversity index $(T)$ demonstrates the diversity of the functional groups within the nematode community. T affords greater weight to common taxa, and a higher index indicates greater diversity (Heip et al., 1988). T valus in the loessial plain area were higher compared with playa area, which revealed that there had greater trophic diversity in the loessial plain area. Pen-Mouratov et al. (2011) observed similar result from the upper soil layer (0 - 10 $\mathrm{cm})$ in the Negev Desert.

Shannon index $\left(H^{\prime}\right)$ affords more weight to rare species, and a high value indicates greater diversity and Simpson index $(\lambda)$ gives more weight to common species (Liang et al., 2002). There had higher $H^{\prime}$ values and lower $\lambda$ values in the loessial plain area in contrast to playa area, as revealed greater diversity in the loessial plain area. $H^{\prime}$ values were higher at $0-10$ and $10-20 \mathrm{~cm}$ soil layers compared with the other layers in the loessial plain area, which manifested that there had greater diversity at $0-10$ and $10-20 \mathrm{~cm}$ soil layers. H' values were significantly influenced by sampling sites and depths (Pen-Mouratov et al., 2008b), whereas $\mathrm{H}$ ' values were significantly influenced only by sampling sites in the present study.

Similarly, spieces richness (SR) values in the loessial plain area were greater than that in the playa area, and also indicating that there had abundant species in the loessial plain area. Yu et al. (2012) found that cultivable microfungal communities inhabiting the playa were lower species diversity compared with the interdune area regardless of soil depths and sampling seasons, which supported our findings.

Maturity index (MI) is a measure based on the composition of the nematode community and can reflect the degree of stability of the soil ecosystem (Bongers, 1990). MI values in the loessial plain area were higher in the wet season than that in the playa area, indicating a relatively higher environmental stability compared with the playa area. MI values significantly negatively correlated with soil organic matter content and electrical conductivity, however, Jiang et al. (2007) reported that MI values significantly positively correlated with soil organic carbon content and electrical conductivity in an age sequence of Caragana microphylla plantations sandy land. Nematode maturity index is modified to include plant-parasitic nematodes (MMI) and thus better reflect ecosystem development (Yeates, 1994), which MMI values also indicated that there had stable environmental conditions in the loessial plain area compared with the playa area.

Enrichment index (EI) provides an indicator of resources available to the soil food web and the response of primary decomposers to those resources (Wang et al., 2006). El values in the loessial plain area were higher than that in the playa area except at $0-10 \mathrm{~cm}$ depth in the wet season, which manifested that there had more sufficiently available nutrient in the loessial plain area. Obvious interaction effect of site and depth on El was found in the stable and active sand dunes of Horqin Sandy Land (Zhang et al., 2010), 
as was different from our findings.

Structure index (SI) reflects the degree of trophic linkage in soil food webs and is an indicator of greater trophic links. Higher SI value indicates a food web that is more structured or stable, with more persisters (k-strategist) genera present (Wang et al., 2006; Briar et al., 2007). Significant sampling sites and depths effects on SI were found in the stable sand dune (Zhang et al., 2010), but only sampling sites effect on SI was observed in the present study. In conclusion, total number of soil free living nematodes, trophic groups and ecological indices used were a good tool for explaining soil habitat environment differences. Soil free-living nematodes inhabited mostly the upper soil layers $(0-20 \mathrm{~cm})$ and nematode abundance was gradually decreasing trend with soil depths increasing in the playa and loessial plain area during the dry and wet seasons. Sampling sites and depths significantly effected on nematode abundance and trophic groups, however, only sampling sites significantly effected on nematode ecological indexes. Moreover, each soil layers had a little nematode abundance and community diversity in a playa area in contrast to loessial plain area during the dry and wet seasons.

\section{Acknowledgements}

This study was partly supported by a Fred and Barbara Kort Sino-Israel Postdoctoral Fellowship to Dr. Cheng Hu. The authors wish to express their appreciation to Mrs. Ginetta Barness for technical assistance.

\section{Conflict of interest}

Authors state no conflict of interest.

\section{Refferences}

Bongers, T. (1990): The maturity index: An ecological measure of environmental disturbance based on nematode species composition. Oecologia, 83: 14 - 19. DOI: 10.1007/BF00324627

BRECKLE, S. W, YAIR, A., Veste, M. (Eds) (2008): Arid Dune Ecosystem: The Nizzana Sands in the Negev Desert. Ecological Studies, Vol. 200, Springer-Verlag Berlin Heidelberg, Germany

Briar, S.S., Grewal, P.S., Somasekhar, N., Stinner, D., Miller, S.A. (2007): Soil nematode community, organic matter, microbial biomass and nitrogen dynamics in field plots transitioning from conventional to organic management. Appl. Soil Ecol., 37: 256 - 266. DOI: 10.1016/j.apsoil.2007.08.004

CAIRNS, E.J. (1960): Methods in nematology. In: SASSER, J.N. JENKINS, W.R. (Eds) Nematology, Fundamentals and Recent Advances with Emphasis on Plant Parasitic and Soil Forms. University of North Carolina Press, Chapel Hill, NC, pp. 33 - 8

FerRIS, H., Bongers, T., De Goede, R.G.M. (2001): A framework for soil food web diagnostics: extension of the nematode faunal analysis concept. Appl. Soil Ecol., 18: 13 - 29. DOI: 10.1016/S0929-
1393(01)00152-4

FerRIS, H., Matute, M.M. (2003): Structural and functional succession in the nematode fauna of a soil food web. Appl. Soil Ecol., 23: 93 - 110. DOI: 10.1016/S0929-1393(03)00044-1

FerRIS, H., VenetTe, R.C., Scow, K.M. (2004): Soil management to enhance bacterivore and fungivore nematode populations and their nitrogen mineralisation function. Appl. Soil Ecol., 25: 19 - 35. DOI: 10.1016/j.apsoil.2003.07.001

GoRALCZYK, K. (1998): Nematodes in a coastal dune succession: Indicators of soil properties? Appl. Soil Ecol., 9: 471 - 475. DOI: 10.1016/S0929-1393(98)00106-1

Guan, P.T., Zhang, X.K., Yu, J., Ma, N.N., LiAng, W.J. (2015): Variation of soil nematode community composition with increasing sand-fixation year of Caragana microphylla: bioindication for desertification restoration. Ecol. Eng., 81 : 93 - 101. DOI: 10.1016/j. ecoleng.2015.04.011

Heip, C., Herman, P. M. J., Soetaert, K. (1988): Data processing, evaluation and analysis. In HIGGINS, R.P., THIEL, H. (Eds) Introduction to the Study of Meiofauna. pp. 197 - 231. (Smithsonian Institution Press: Washington, DC)

Hu, C., QI, Y.C. (2013): Effective microorganisms and compost favor nematodes in wheat crops. Agron. Sustain. Dev., 33: 573 579. DOI: 10.1007/s13593-012-0130-9

Hu, C., XIA, X.G., Han, X.M., Chen, Y.F., QIAO, Y., LIU, D.H., LI, S.L. (2018): Soil nematode abundances were increased by an incremental nutrient input in a paddy-upland rotation system. Helminthologia, 55: 322 - 333. DOI: 10.2478/helm-2018-0025

JIANG, D.M., LI, Q., LIU, F.M., JIANG, Y., LIANG, W.J. (2007): Vertical distribution of soil nematodes in an age sequence of Caragana microphylla plantations in the Horqin Sandy Land, Northeast China. Ecol. Res., 22: 49 - 56. DOI: 10.1007/s11284-006-0187-5

Keck, H., Felde, V.J.M.N.L., Drahorad, S.L., Felix-Henningsen, P. (2016): Biological soil crusts cause subcritical water repellency in a sand dune ecosystem located along a rainfall gradient in the NW Negev desert, Israel. J. Hydrol. Hydromech., 64: 133 - 140. DOI: 10.1515/johh-2016-0001

KIDRON, G.J. (2001): Runoff-induced sediment yield over dune slopes in the Negev desert. 2: texture, carbonate and organic matter. Earth Surf. Proc. Land., 26: 583 - 599. DOI: 10.1002/esp.194 KidRon, G.J., VonshaK, A., Abeliovich, A. (2009): Microbiotic crusts as biomarkers for surface stability and wetness duration in the $\mathrm{Ne}$ gev Desert. Earth Surf. Processes Landf., DOI: 10.1002/esp.1843 KidRon, G. J., Vonshak, A., Abelovich, A. (2008): Recovery rates of microbiotic crusts within a dune ecosystem in the Negev Desert. Geomorphology, 100: 444 - 452. DOI: 10.1016/j.geomorph.2008.01.012

KIDRON, G.J., YAIR, A. (2001): Run-off induced sediment yield over dune slopes in the Negev desert. 1: quantity and variability. Earth Surf. Proc. Land., 26: 461 - 474. DOI: 10.1002/esp.191

Liang, W., LaVIAN, I., Steinberger, Y. (1999): Dynamics of nematode community composition in a potato field. Pedobiologia, 43: 459 469 
LIANG, W., SteinBerger, Y. (2001): Temporal changes in nematode community structure in a desert ecosystem. J. Arid Environ., 48: 267 - 280. DOI: 10.1006/jare.2000.0758

Liang, W.J., Mouratov, S., Pinhasi-Adiv, Y., Avigad, P., Steinberger, Y. (2002): Seasonal variation in the nematode communities associated with two halophytes in a desert ecosystem. Pedobiologia, 46: 63 - 74. DOI: 10.1078/0031-4056-00114

Liang, W.J., Zhang, X.K., Li, Q., Jiang, Y., Ou, W., Neher, D.A. (2005): Vertical distribution of bacterivorous nematodes under different land uses. J. Nematol., 37: $254-258$

LIU, T., Hu, F., LI, H.X. (2019): Spatial ecology of soil nematodes: Perspectives from global to micro scales. Soil Biol. Biochem., 137: 107565. DOI: 10.1016/j.soilbio.2019.107565

MAL, W.F., LYoN, H.H. (1975): Pictorial key to genera of pant-parasitic nematodes. Cornell University Press. Ithaca \& London. pp $1-219$

NeHER, D.A. (2001): Role of nematodes in soil health and their use as indicators. J. Nematol., 33: $161-168$

OU, W., LIANG, W.J., JIANG, Y., LI, Q.,WEN, D.Z. (2005): Vertical distribution of soil nematodes under different land use types in an aquic brown soil. Pedobiologia, 49: 139 - 148. DOI: 10.1016/j. pedobi.2004.10.001

Pen-mouratov, S., Barness, G., Steinberger, Y. (2008a). Effect of desert plant ecophysiological adaptation on soil nematode communities. Eur. J. Soil Biol. 44: 298 - 308. DOl: 10.1016/j.ejsobi.2008.03.005

Pen-Mouratov, S., Hu, C., Hindin, E., Steinberger, Y. (2011): Soil microbial activity and a free-living nematode community in the playa and in the sandy biological crust of the Negev Desert. Biol. Fert. Soils, 47: 363 - 375. DOI: 10.1007/s00374-011-0540-x

Pen-Mouratov, S., Rakhimbaev, M., Barness, G., Steinberger, Y. (2004): Spatial and temporal dynamics of nematode populations under Zygophyllum dumosum in arid environments. Eur. J. Soil Biol., 40: 31 - 46. DOI: 10.1016/j.ejsobi.2004.01.002b

Pen-Mouratov, S., Rodriguez-Zaragoza, S., Steinberger, y. (2008b): The effect of Cercidium praecox and Prosopis laevigata on vertical distribution of soil free-living nematode communities in the Tehuacán Desert, Mexico. Ecol. Res. 23, 973 - 982. DOI: 10.1007/s11284-008-0464-6

Rahman, L., Whitelaw-Weckert, M.A., Hutton, R.J., Orchard, B. (2009): Impact of floor vegetation on the abundance of nematode trophic groups in vineyards. Appl. Soil Ecol., 42 : 96 - 106. DOI: 10.1016/j.apsoil.2009.02.006

RoweLL, D. L. (1994): Soil Science: Methods and Applications, Longman Group UK Ltd., London.

RUESS, L. (2003): Nematode soil faunal analysis of decomposition pathways in different ecosystems. Nematology, 5: $179-181$. DOI: $10.1163 / 156854103767139662$

Shamir, I., Steingerger, Y. (2007): Vertical distribution and activity of soil microbial population in a sandy desert ecosystem. Microb. Ecol., 53: 340 - 347. DOI: 10.1007/s00248-006-9137-6

Shannon, C.E., Weaver, W. (1949): The Mathematical Theory of
Communication. University of Illinois Press: Urbana, IL.

Siebert, J., Ciobanu, M., Schädler, M., Elsenhauer, N. (2019): Climate change and land use induce functional shifts in soil nematode communities. Oecologia, DOI: 10.1007/s00442-019-04560-4 SIMPSON, E.H. (1949): Measurement of diversity. Nature, 163: 668 SteInBERGER, Y, SARIG, S. (1993): Response by soil nematode populations in the soil microbial biomass to a rain episode in the hot, dry Negev Desert. Biol. Fert. Soils, 16: 188 - 192. DOI: 10.1007/ BF00361406

TER BRAaK C.J.F., SMILAUER, P. (2002): CANOCO Reference Manual and CanoDraw for Windows User's Guide: Software for Canonical Community Ordination (Version 4.5). Biometrics: Wageningen and České Budějovice

ter BRAak, C.J.F., PrenticE, I.C. (1996): A theory of gradient analysis. In Ter BraAK, C.J.F. (Ed) Unimodal Models to Related Species Environment. DLO-Agricultural Mathematics Group: Wageningen. pp. $138-271$

Twinn, D.C. (1974): Nematodes. In Dickinson, C.H., Pugh, G.J.F. (Eds) Biology of Plant Litter Decomposition. Academic Press: London. pp. $421-465$

Wall, J.W., Skene, K.R., Nellson, R. (2002): Nematode community and trophic structure along a sand dune succession. Biol. Fert. Soils, 35: 293 - 301. DOI: 10.1007/s00374-002-0478-0

Wang, K.-H., Mcsorley, R., Marshall, A., Gallaher, R.N. (2006): Influence of organic crotalaria juncea hay and ammonium nitrate fertilizers on soil nematode communities. Appl. Soil Ecol., 31: 186 - 198. DOI: 10.1016/j.apsoil.2005.06.006

YAIR, A. (1990). Runoff generation in a sandy area - the Nizzana sands, Western Negev, Israel. Earth Surf. Process. Landf., 15, 597 - 609. DOI: 10.1002/esp.3290150703

YANG, H.Y., LIU, C.Z., LIU, Y.M., XING, Z.S. (2018): Impact of human trampling on biological soil crusts determined by soil microbial biomass, enzyme activities andnematode communities in a desert ecosystem. Eur. J. Soil Biol., 87: 61 - 71. DOI: 10.1016/j. ejsobi.2018.05.005

YeATES, G.W. (1994): Modification and qualification of the nematode maturity index. Pedobiologia, 38: 97 - 101

YeATES, G.W. (2003): Nematodes as soil bioindicators: functional and biodiversity aspects. Biol. Fert. Soils, 37: $199-210$. DOI: 10.1007/s00374-003-0586-5

YeATES, G.W., Bongers, T. (1999): Nematode diversity in agroecosystems. Agr. Ecosyst. Environ. 74: 113 - 135.

Yeates, G.W., Bongers, T., De Goede, R.G.M., Freckman, D., GeorGIEVA, S.S. (1993): Feeding habits in soil nematode families and genera - an outline for soil ecologists. J. Nematol., 25: 315 - 331 YeAtES, G.W., KING, K.L. (1997): Soil nematodes as indicators of the effect of management on grasslands in the New England Tablelands (NSW): Comparison of native and improved grasslands. Pedobiologia, 41: $526-536$

YING, W.Y. (1998): Pictorial keys to soil animals of China. Beijing: China Science Press, pp 51-89

Yu, J., Grishikan, I., Sherman, C., Steinberger, Y. (2012): Spatiotem- 
poral variability of cultivable microfungal communities inhabiting a playa area in the western Negev Desert, Israel. J. Arid Environ. 81: 9-17. DOI: 10.1016/j.jaridenv.2012.01.005

Zhang, X.K., Dong, X.W., LIANG, W.J. (2010): Spatial distribution of soil nematode communities in stable and active sand dunes of Horqin sandy land. Arid Land Res. Manag., 24: 68 - 80. DOI:

\subsection{0/15324980903439321}

ZHANG, X.K., LIANG, W.J., JiANG, D.M., LIU, Z.M., JIANG, S.W. (2007): Soil nematode community structure in a Chinese sand dune system. Helminthologia, 44: 204 - 209. DOI: 10.2478/s11687-0070032-6 